\title{
Multiresistance Genes of Rhizobium etli CFN42
}

\author{
Ramón González-Pasayo ${ }^{1,2}$ and Esperanza Martínez-Romero' \\ ${ }^{1}$ Centro de Investigación sobre Fijación de Nitrógeno, and ${ }^{2}$ Facultad de Ciencias, Universidad Nacional \\ Autónoma de México, Apartado Postal 565-A, Cuernavaca, Morelos, México \\ Accepted 12 January 2000.
}

\begin{abstract}
Multidrug efflux pumps of bacteria are involved in the resistance to various antibiotics and toxic compounds. In Rhizobium etli, a mutualistic symbiont of Phaseolus vulgaris (bean), genes resembling multidrug efflux pump genes were identified and designated $r m r A$ and $r m r B$. rmrA was obtained after the screening of transposongenerated fusions that are inducible by bean-root released flavonoids. The predicted gene products of $r m r A B$ shared significant homology to membrane fusion and major facilitator proteins, respectively. Mutants of $r m r A$ formed on average $40 \%$ less nodules in bean, while mutants of $r m r A$ and $r m r B$ had enhanced sensitivity to phytoalexins, flavonoids, and salicylic acid, compared with the wild-type strain. Multidrug resistance genes emrAB from Escherichia coli complemented an rmrA mutant from $R$. etli for resistance to high concentrations of naringenin.
\end{abstract}

Rhizobia form nitrogen-fixing nodules on the roots of legumes. Nodule formation is a complex process that is initiated with the release of flavonoids by the legume root and these compounds induce the expression of Rhizobium spp. symbiotic genes (Hanin et al. 1999; Perret et al. 1999). In the interaction with symbionts, such as mycorrhizae (Hirsch and Kapulnik 1998) and rhizobia (Baron and Zambryski 1995; Spaink 1995), some of the plant defense responses are triggered. For example, legumes produce phytoalexins in response to various biological, chemical, or physical stresses (Kuc 1995) as well as to the presence of rhizobia (Dakora et al. 1993; Schmidt et al. 1994; Wolff and Werner 1990). These bacteria can survive antibacterial concentrations of phytoalexins either by acquired resistance (Parniske et al. 1991) or by their ability to catabolize these compounds (Rao and Cooper 1994).

In Phaseolus vulgaris (bean), flavonoid phytoalexins such as phaseollin, phaseollinisoflavan, phaseollidin, kievitone, and coumestrol increase upon wounding, by abiotic stresses, and also in response to viruses or pathogenic rhizobacteria (Dixon

Corresponding author: Esperanza Martínez-Romero; Address: Centro de Investigación sobre Fijación de Nitrógeno, Universidad Nacional Autónoma de México, Apartado Postal 565-A, Cuernavaca, Morelos, México; Telephone: (52) (73) 13 16 97; Fax: (52) (73) 1755 81; E-mail: martine@cifn.unam.mx

Nucleotide and/or amino acid sequence data can be found at the GenBank data base as accession no. AF233286.
1986). R. etli exopolysaccharide (EPS ${ }^{-}$) or lipopolysaccharide $\left(\mathrm{LPS}^{-}\right)$mutants display enhanced sensitivity to coumestrol and other coumestans from bean roots, indicating that EPS and LPS may act as barriers to restrain the entry of root inhibitory compounds into Rhizobium etli cells (Eisenschenk et al. 1994). In addition, $R$. etli EPS and LPS have been implicated in actively suppressing the plant defense response (Niehaus et al. 1993). Salicylic acid is another phenolic compound that has been implicated in plant defense against pathogens (Klessig and Malamy 1994). R. meliloti nodulation factors have been reported to inhibit the salicylic acid-mediated defense response in alfalfa (Martínez-Abarca et al. 1998).

The main $P$. vulgaris nodule isolates in Mesoamerica are $R$. etli strains (Segovia et al. 1993). Here, we describe the identification in $R$. etli of genes resembling the multidrug resistance (MDR) loci from microbial pathogens and present their structural and functional characterization. We also propose a role for the $\operatorname{rmrAB}$ (Rhizobium multiresistance) gene products in phytoalexin and salicylic acid resistance in $R$. etli.

$R$. etli CFN42 derivatives carrying Tn5-B30 (Simon et al. 1989) with a promoterless nptII reporter gene were obtained by mating Escherichia coli S17-1 (Simon et al. 1983) containing pSUP102::Tn5-B30 with strain CFN42 (Table 1). The $R$. etli CFN42 mutants were tested for growth in modified PY media $\left(0.25 \%\right.$ peptone, $0.15 \%$ yeast extract, and $\left.7 \mathrm{mM} \mathrm{CaCl}_{2}\right)$ containing different kanamycin concentrations in the presence or absence of root exudates (obtained as described by Rosenblueth et al. 1998) or with naringenin $(1.2 \mu \mathrm{M})$. Naringenin, genistein, and other flavonoids are inducers of $R$. etli nodulation genes and have been found in bean exudates (Hungria et al. 1991). Bacteria that grew in the presence of bean root exudates or naringenin but not in their absence were considered to be mutated on genes up-regulated by root exudates or flavonoids. A mutant, CFNEA31, whose growth on kanamycin $\left(100 \mu \mathrm{g} \mathrm{ml}^{-1}\right)$ was dependent on naringenin $(1.2 \mu \mathrm{M})$ but also on genistein $(0.4 \mu \mathrm{M})$, quercetagetin $(1.0 \mu \mathrm{M})$, or chrysin $(1.0$ $\mu \mathrm{M})$, was selected for further analysis. The flavonoiddependent growth of CFNEA31 was also estimated in liquid MM containing kanamycin by measuring cell densities at $\mathrm{OD}_{600}$. The MM had the following composition (per liter of demineralized water): sucrose, $2 \mathrm{~g} ; \mathrm{K}_{2} \mathrm{HPO}_{4}, 0.17 \mathrm{~g} ; \mathrm{MgSO}_{4}$, $0.25 \mathrm{~g} ; \mathrm{KNO}_{3}, 0.01 \mathrm{~g} ; \mathrm{KH}_{2} \mathrm{PO}_{4}, 1.0 \mathrm{~g} ; \mathrm{NaCl}, 0.16 \mathrm{~g}$; Fe citrate, $1.2 \mathrm{~g}$; $\mathrm{CaCl}_{2}, 1.2 \mathrm{~g}$; biotin, $10 \mu \mathrm{g}$; and trace minerals (Fahraeus 1957). In two separate experiments, we found significantly higher growth in kanamycin in the presence of genistein $(5 \mu \mathrm{M})$ than in its absence $(P<0.01$; Fig. 1). Cell 
growth studies also included cultures of strain CFNEA31 grown in the absence of kanamycin. The addition of genistein up to 5 $\mu \mathrm{M}$ did not affect growth of the wild-type strain CFN42 in MM.

The location of the Tn5-B30 insertion in the CFNEA31 genome was determined with the plasmid-cured CFN42 derivatives CFNX182 and CFNX183 (Brom et al. 1992). In a Southern blot hybridization, the flanking sequences of the insert (cloned in pUC18) hybridized to CFNX182 but not to CFNX183 (cured of plasmid b). Hybridization was also obtained to cosmid pCOS126 (Cava et al. 1989) from CFN42 plasmid b (which carries LPS genes; Sambrook et al. 1989) and localized to two EcoRI fragments of 1.3 and $5.6 \mathrm{~kb}$ (Fig. 2A), which were subsequently cloned and used for sequencing. The 1.3-kb DNA fragment and a 3.7-kb fragment from the $5^{\prime}$ end of the $5.6-\mathrm{kb}$ subclone were sequenced by primer walking with a 373A automated DNA sequencer and Taq DyeDeoxy Terminator Cycle Sequencing kits (Applied Biosystems, Foster City, CA). The flanking regions of Tn5-B30 obtained from CFNEA31 were sequenced and their alignment with the wild-type sequence derived from pCOS126 subclones allowed us to determine that the Tn5-B30 in CFNEA31 was inserted 299 bp downstream of the start codon of an open reading frame (ORF1) of 1,191 bp. ORF1 is preceded by a potential ribosomal binding site (RBS) and encodes a predicted $41.8-\mathrm{kDa}$ protein that was compared with protein sequences in the NCBI data bases with the BLAST program (Altschul et al. 1990) and pairwise alignments with GCG Gap (Henikoff and Henikoff 1992) to estimate the identity (I) and similarity (S) scores. Homology was observed over the entire length of the ORF1 putative protein with the EmrK (accession no. P52599) and EmrA (accession no. 27303) multiresistance proteins from E. coli $(34.3 \% \mathrm{I}, 53.5 \% \mathrm{~S}$ and $34.0 \%$ I, $52.1 \%$ $\mathrm{S}$, respectively), the VceA protein from Vibrio cholerae (31.7\% I, 50.0\% S) (accession no. 2815577), and the EmrA protein from Haemophilus influenzae (29.8\% I, 49.7\% S) (accession no. P44928).
An ORF of 1,581 bp (ORF2) was found downstream of ORF1 (Fig. 2A) in the same orientation. ORF2 was also preceded by a potential RBS and encoded a predicted $56.1-\mathrm{kDa}$ protein with homology over their entire lengths to VceB from $V$. cholerae $(29.3 \% \mathrm{I}, 55.6 \% \mathrm{~S})$ (accession no. 2815578),

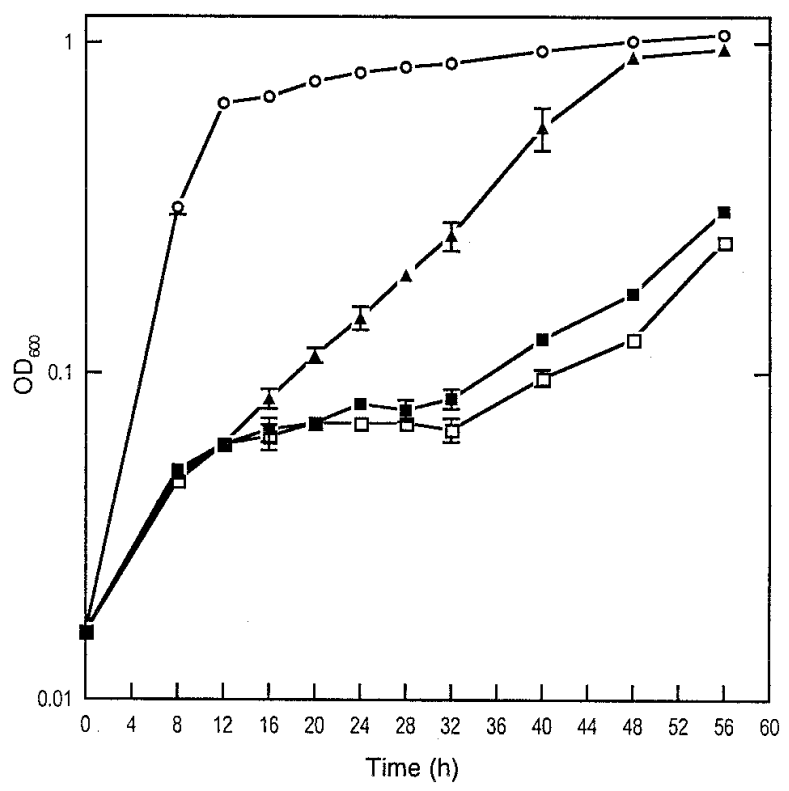

Fig. 1. Growth dependence of CFNEA31 mutant on genistein in the presence of kanamycin. Growth of CFNEA31, carrying the nptII kanamycin resistance gene as a promoter probe from $\mathrm{Tn} 5: \mathrm{B} 30$, was screened by testing kanamycin $(100 \mu \mathrm{g} / \mathrm{ml})$ resistance with genistein $1 \mu \mathrm{M}(\mathbf{\square}), 5 \mu \mathrm{M}(\mathbf{\Delta})$, or without genistein ( $\square$ ). As a control, growth of CFNEA31 without kanamycin was measured $(O)$. Statistical significance of differences between treatments was determined with a $t$ test $(P<0.01)$. Growth was measured by increase of $\mathrm{OD}_{600}$ (optical density at $600 \mathrm{~nm}$ ); values are means from three replicates \pm standard errors represented by bars.

Table 1. Bacterial strains and plasmids

\begin{tabular}{|c|c|c|}
\hline Strain or plasmid & Characteristics $^{\mathbf{a}}$ & Reference \\
\hline \multicolumn{3}{|l|}{ Strain } \\
\hline \multicolumn{3}{|l|}{ Rhizobium etli } \\
\hline CFN42 & Wild type, $\mathrm{Nal}^{\mathrm{r}}$ & Segovia et al. 1993 \\
\hline CFNX182 & CFN42 cured of plasmid a, pa & Brom et al. 1992 \\
\hline CFNX183 & CFN42 cured of plasmid $b$, pb & Brom et al. 1992 \\
\hline CFNEA31 & CFN42 rmrA::Tn5-B30, $\mathrm{Tc}^{\mathrm{r}}$ & This study \\
\hline CFNEA32 & CFNEA31 harboring pCOS126, $\mathrm{Tc}^{\mathrm{r}}$ & This study \\
\hline CFNEA31pLAFR1 & CFNEA31 harboring pLAFR $1, \mathrm{Tc}^{\mathrm{r}}$ & This study \\
\hline CFNEA33 & CFNEA31 harboring pRK7813emrAB, $\mathrm{Tc}^{\mathrm{r}}$ & This study \\
\hline CFNEA31pRK7813 & CFNEA31 harboring pRK7813, $\mathrm{Tc}^{\mathrm{r}}$ & This study \\
\hline CFNEA34 & CFN42 rmrA::pWS233 & This study \\
\hline CFNEA35 & CFN42 rmrB::pWS233 & This study \\
\hline \multicolumn{3}{|l|}{ Escherichia coli } \\
\hline DH5a & $\operatorname{rec} A 1, \Delta l a c Z, \mathrm{Nal}^{\mathrm{r}}$ & Sambrook et al. 1989 \\
\hline S17-1 & Modified RP4 integrated into chromosome & Simon et al. 1983 \\
\hline \multicolumn{3}{|l|}{ Plasmids } \\
\hline pLAFR1 & Broad-host-range cloning vector, $\mathrm{Tc}^{\mathrm{r}}$ & Friedman et al. 1982 \\
\hline pCOS126 & $27 \mathrm{~kb}$ of CFN42 pb in pLAFR 1 & Cava et al. 1989 \\
\hline pRK7813 & Broad-host-range cosmid vector, Mob, IncP, $\mathrm{Tc}^{\mathrm{r}}$ & Jones and Gutterson 1987 \\
\hline pSE380emrAB & pSE380 vector carrying $e m r A B$ & O. Lomovskaya, unpublished \\
\hline $\mathrm{pRKemr} A B$ & pRK7813 vector carrying $e m r A B$ & This study \\
\hline pSUP102 & Containing $\operatorname{Tn} 5-\mathrm{B} 30, \mathrm{Tc}^{\mathrm{r}}$ & Simon et al. 1989 \\
\hline pUC18 & Multicopy cloning vector & Messing 1983 \\
\hline pWS233 & Cloning vector, $\operatorname{sac} R B, \mathrm{Gm}^{\mathrm{r}}, \mathrm{Tc}^{\mathrm{r}}$ & Selbitschka et al. 1993 \\
\hline
\end{tabular}

${ }^{a} \mathrm{Gm}$, gentamicin; Nal, nalidixic acid; Sm, streptomycin; Tc, tetracycline; sac, levansucrase gene; r, resistant. 


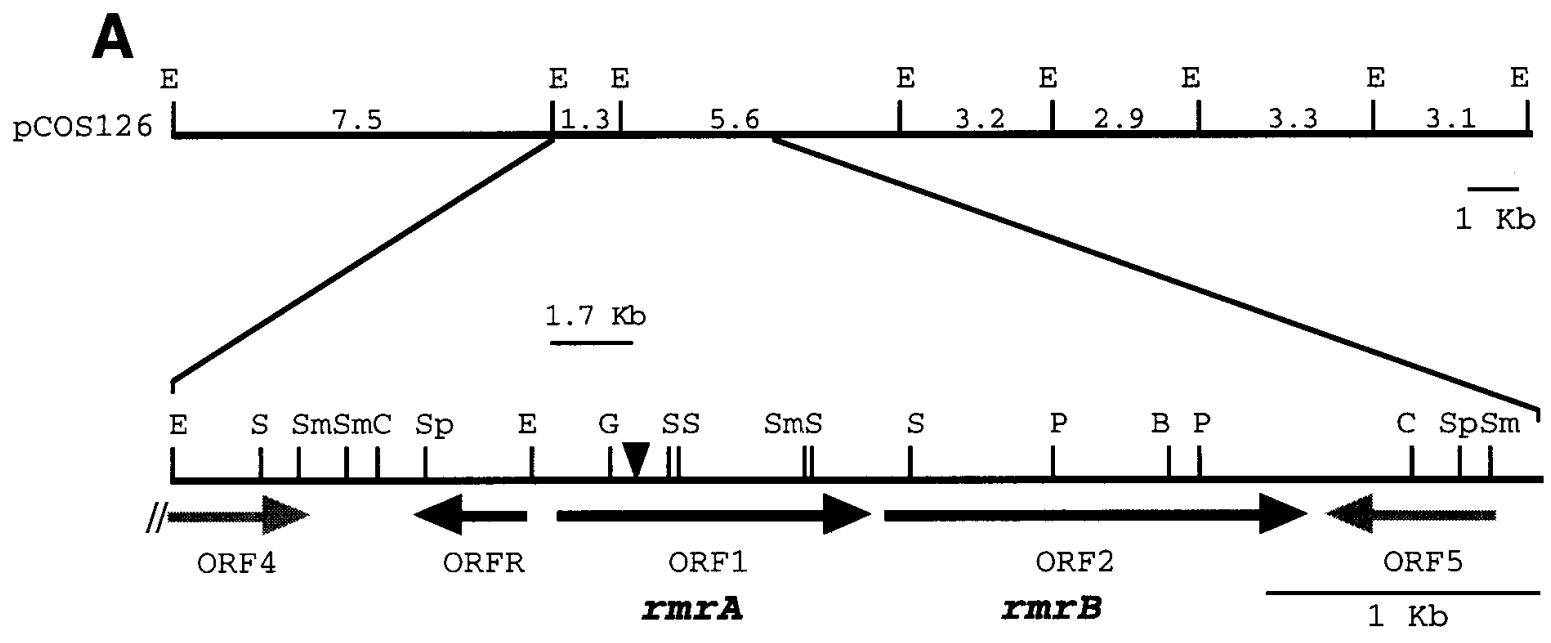

B

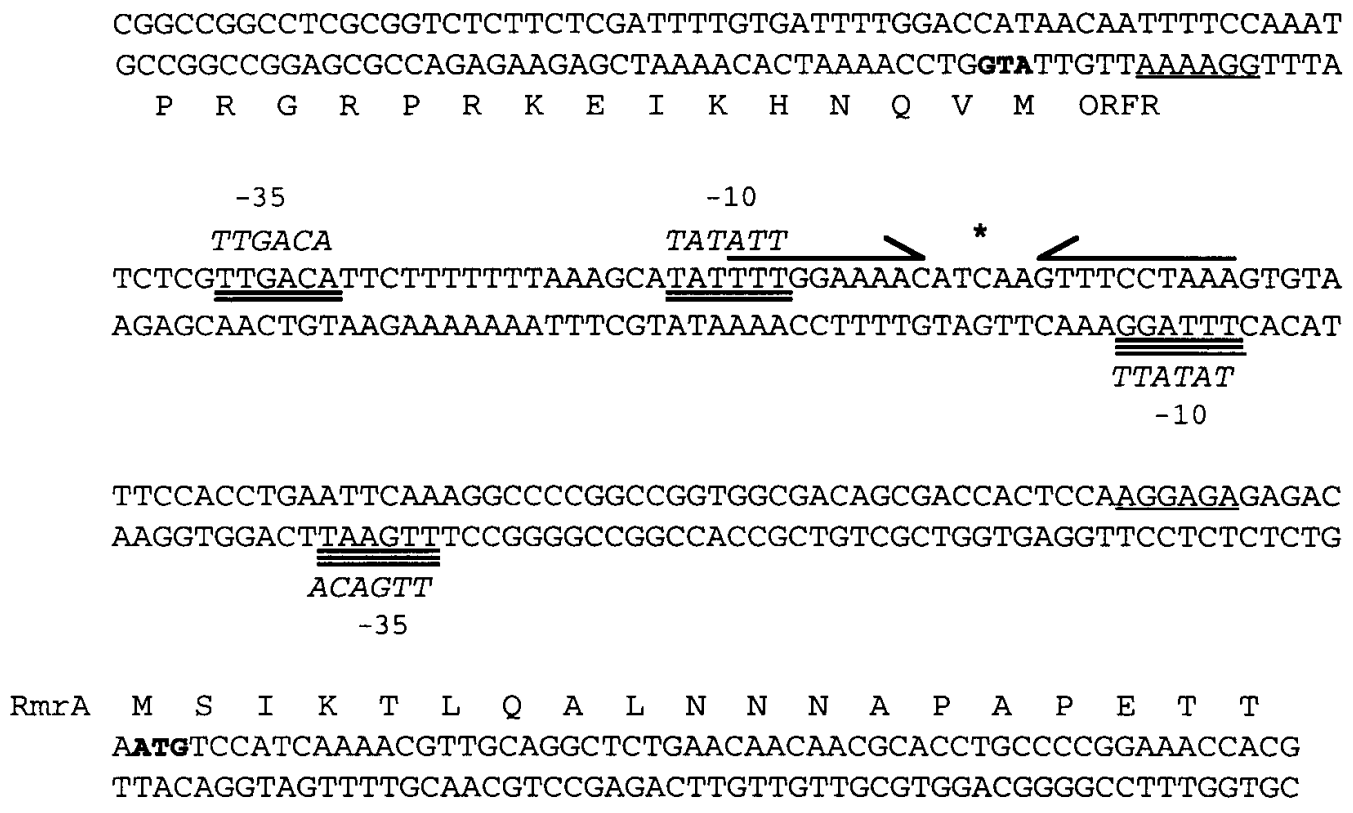

Fig. 2. $r m r$ gene organization. A, EcoRI restriction map of cosmid pCOS126. Numbers above map indicate sizes of EcoRI fragments in kb. Physical map and genetic organization of the 5.0-kb region sequenced (accession no. AF233286) is also indicated, showing the 1.3-kb EcoRI fragment and 3.7 kb from the $5^{\prime}$ end site of 5.6-kb EcoRI fragment. Location of the Tn5-B30 insertion is indicated by an arrowhead. Black arrows indicate position and direction of transcription of putative open reading frames (ORFs) ORF1, ORF2, and ORF3. Gray arrows indicate neighboring ORFs: ORF4, with high homology to manonate dehydratase from the glucuronic acid pathway and ORF5, with homology to phosphotransferase from Lactococcus lactis. Relative position of the 1.7-kb HindIII fragment used as a probe for isolation of pCOS126 is indicated above restriction map. Restriction endonuclease sites: B, BamHI; C, ClaI; E, EcoRI; G, BglII; P, PstI; S, SalI; Sm, SmaI; Sp, SphI. B, rmrA and ORFR intergenic region and fragments of amino terminal sequences of gene products. Predicted start codons are shown in bold. Putative ribosomal binding site (RBS) sequences are underlined. Potential promoter sequences ( -35 and -10$)$ of $r m r A$ and ORFR are underlined twice and three times, respectively. Italics indicate -35 and -10 consensus sequence for $\sigma^{70}$ dependent promoter. Two regions of dyad symmetry corresponding to a potential regulatory site are marked by half-arrowed lines. * indicates midpoint of palindrome. 
EmrB from E. coli (28.2\% I, 53.2\% S) (accession no. 27304), EmrB from $H$. influenzae (26.3\% I, 53.8\% S) (accession no. P44927), and EmrY from E. coli $(25.5 \%$ I, $53.4 \% \mathrm{~S})$ (accession no. 52600). These proteins exhibited the greatest degree of sequence similarity in their N-terminal regions. This feature was found in previous analyses of MDR proteins (Marger and Saier 1993; Paulsen and Skurray 1993) and it was suggested that the conserved sequence may be involved in common functions, such as proton translocation, while specialized functions, such as substrate binding, are encoded by the C-terminal regions (Rouch et al. 1990). The drug extrusion consensus (GxhhGPxIGG, with " $x$ " as any amino acid; and " $h$ " as hydrophobic; upper case, high frequency of occurrence), a highly conserved motif of exporters of the major facilitator superfamily (Lewis 1994; Marger and Saier 1993; Paulsen and Skurray 1993), was identified within the ORF2 protein sequence.

A nucleotide sequence similar to the $E$. coli and B. japonicum $\sigma^{70}$ (the major sigma factor used for normal growth conditions in $E$. coli) consensus binding sequence (Beck et al. 1997; Lisser and Margalit 1993) was identified upstream of ORF1. This sequence is identical to the -35 E. coli/B. japonicum region and five out of six nucleotides of the -10 site were conserved (Fig. 2B). An additional feature of this region is a dyad symmetry at the $5^{\prime}$ end of ORF1, which may be a regulatory palindrome. Neither promoter sequence nor putative transcription terminator were found immediately upstream of ORF2 and the distance between the TAG translation stop codon of ORF1 and the ATG translation initiation codon of ORF2 is $24 \mathrm{bp}$, suggesting that the two genes could be organized into an operon. Moreover, a potential transcription terminator (AAGCCCTCCTTTATCCGGAAAGGAGGGCTT) was found downstream of ORF2. No nod box (Rostas et al. 1986) or A3-like sequence (Mao et al. 1994) was identified in 400 bp upstream of ORF1.

A hydrophobicity analysis was performed with the Gene Works package (release 2.4; IntelliGenetics, Mountain View, CA) (Kyte and Doolittle 1982) and Psort program (Nakai and Kanehisa 1991) to examine the predicted proteins for potential hydrophobic and hydrophilic regions. The ORF1 putative protein showed a hydrophobic domain at the amino terminal region, forming a single $\alpha$-helix that spans the membrane (between amino acids 54 and 70) and a large, hydrophilic, Cterminal domain that could be located in the periplasm. This hydropathy pattern is conserved in EmrA (Lomovskaya and Lewis 1992) and in VceA (Colmer et al. 1998). In the case of the ORF2 putative protein, the analysis revealed 14 hydrophobic domains that may form transmembrane $\alpha$-helical segments, which is a pattern also conserved in EmrB (Lomovskaya and Lewis 1992) and VceB (Colmer et al. 1998) (data not shown).

Based on the similarity in sequence, length, hydropathy plots, and proteins encoded by genes adjacent to EmrA and VceA, the protein encoded by ORF1 was included in the membrane fusion protein (MFP) family and designated RmrA (Rhizobium multiresistance gene $\underline{\mathrm{A}}$ ). The MFPs may cause fusion of the inner and outer membranes, as proposed by Saier et al. (1994). Based on its similarity at the amino acid level with $\mathrm{EmrB}$, the hydropathy profile, and the presence of the extrusion consensus sequence, the ORF2 putative protein may be included in the major facilitator superfamily (Pao et al.
1998), in particular, the drug-resistance protein family (Griffith et al. 1992; Marger and Saier 1993), and was therefore named RmrB. This group of transporter proteins share a common structure and function. They are integral membrane proteins with 12 to 14 transmembrane segments and they confer drug efflux driven by proton motive force (Marger and Saier 1993).

A third ORF of $357 \mathrm{bp}$, oriented in the opposite direction and named ORFR, was also identified 136 bp upstream of $r m r A$ (Fig. 2A). Analysis of the protein sequence deduced from ORFR showed that it encodes a putative 13.0-kDa protein that is similar to members of the TetR-AcrR family (Hinrichs et al. 1994). ORFR product contains a helix-turnhelix motif similar to that of proteins that exert transcriptional control. Upstream of ORFR, an RBS was localized, as well as a potential promoter (Fig. 2B). This potential promoter overlaps the $r m r A$ upstream sequence between the ATG start codon and putative promoter of $r m r A$. This organization is similar to that of the qacA gene (encoding an efflux transporter of quaternary ammonium antiseptics and some basic dyes in Staphylococcus aureus) and its putative regulator, ORF188 (Rouch et al. 1990). The protein encoded by ORFR could be involved in regulating $r m r A B$ but this possibility remains to be tested.

With the sacRB-containing vector, pWS233, (Selbitschka et al. 1993) two additional mutants of $R$. etli CFN42 (CFNEA34 and CFNEA35) were obtained by mutagenesis of $r m r A$ and $r m r B$ genes, respectively (Table 1). The mutant strains (CFNEA31, CFNEA34, and CFNEA35) and the wild-type strain CFN42 had identical growth rates in PY medium (per liter: $5 \mathrm{~g}$ of peptone, $3 \mathrm{~g}$ of yeast extract, and $1 \mathrm{~g}$ of $\left.\mathrm{CaCl}_{2} \cdot \mathrm{H}_{2} \mathrm{O}\right)$ and $\mathrm{MM}$ media (data not shown).

The bean-nodulating ability of strains CFNEA31, CFNEA31 (pLAFR1; see below for the details of genetic construction), and CFNEA34 was diminished, compared with the wild-type strain $(P<0.01)$ and was restored in CFNEA32, which contains the plasmid pCOS126 (Fig. 3). In three independent experiments, $r m r A$ mutants CFNEA31 and CFNEA34 produced an average of $40 \%$ less nodules, when compared with the wild-type strain. A smaller decrease in nodulation was observed with CFNEA35 (data not shown). The nodules were otherwise morphologically unaltered and fixed nitrogen. CFNEA31 produced Nod factors identical to those of the wild-type strain and its LPS profiles and motility were unaltered (data not shown).

To study the role of the RmrAB with regard to tolerance to toxic compounds we used different compounds at concentrations that may be toxic in MM plates and liquid MM. On plates with MM, CFNEA31 was unable to grow in the presence of $0.2 \mathrm{mM}$ phaseollin and $0.1 \mathrm{mM}$ phaseollidin while growth of CFN42 was obtained. In liquid MM, in experiments similar to those performed when determining minimal inhibitory concentration (Colmer et al. 1998), there was no growth of strains CFNEA31, CFNEA34, and CFNEA35 in the presence of $735 \mu \mathrm{M}$ naringenin, $1.2 \mathrm{mM}$ coumaric acid, or $725 \mu \mathrm{M}$ salicylic acid. In contrast, the wild-type strain grew even at higher concentrations of these compounds (1.1 mM naringenin, $1.8 \mathrm{mM}$ coumaric acid, or $3.6 \mathrm{mM}$ salicylic acid). The 4-kb EcoRI-HindIII fragment of pSE380emrAB (O. Lomovskaya, unpublished) containing emrAB from E. coli was cloned into pRK7813 (Jones and 
Gutterson 1987), yielding pRKemrAB. The cosmids pLAFR1 and pCOS126 and the plasmids pRK7813 and pRKemrAB were transferred to CFNEA31 in matings from E. coli S17-1. Transconjugants were selected in PY medium supplemented with $10 \mu \mathrm{g} \mathrm{ml}^{-1}$ nalidixic acid and $25 \mu \mathrm{g} \mathrm{ml}^{-1}$ tetracycline. CFNEA31 complemented with pCOS126 (strain CFNEA32) or with pRKemrAB (strain CFNEA33) grew in the presence of $300 \mu \mathrm{g} \mathrm{ml}^{-1}$ naringenin, as did the wild-type controls, while the growth of CFNEA31 with either pLAFR1 or pRK7813 was completely inhibited. These complementations suggest a functional similarity between the products of the $E$. coli emrAB genes and of the $r m r A B$ locus of $R$. etli CFN42.

The MDR system is found mostly in pathogens and to our knowledge has not been previously described in rhizobia. Agrobacterium tumefaciens, a pathogen related to rhizobia, forms tumors on a variety of dicotyledonous plants. This pathogen possesses an efflux pump inducible by alfalfa isoflavonoids that is required for competitive colonization of the bacteria of alfalfa roots (Palumbo et al. 1998). Our findings support the notion discussed by Saier et al. (1998) that the MDR systems have not arisen recently as a result of extensive exposure of microorganisms to drugs and that they play important physiological roles in the extrusion of natural toxic substances. We propose that $r m r A B$ encodes an inducible export system that prevents the accumulation of toxic plant compounds within the bacterial cell, thereby conferring an advantage to $R$. etli for bean nodulation.

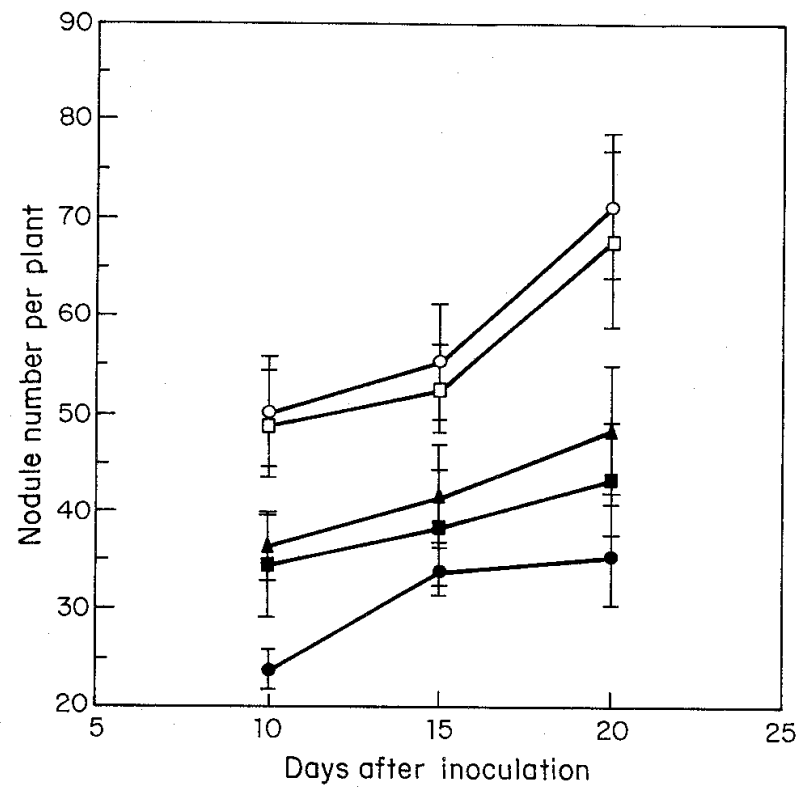

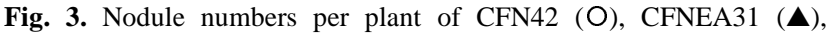
CFNEA32 (CFNEA31 complemented with pCOS126, $\square$ ), CFNEA34 $(\bullet)$, and CFNEA31 (pLAFR1) (ロ) on beans. Seeds of Phaseolus vulgaris cv. Negro Jamapa or N-8-116 were surface sterilized. Two-day-old seedlings were transfered to 250-ml Erlenmeyer flasks containing agar or vermiculite with nitrogen-free Fahraeus medium (Fahraeus 1957). One hundred microliters with around $10^{6}$ cells of each bacterial suspension was used per plant as inoculum. Mean number of nodules from five plants was determined at 10,15 , or 20 days post inoculation. Statistical significance of differences between treatments was determined with a $t$ test $(P<0.01)$. Bars represent standard errors. Two independent plants assays were performed; data for one experiment are presented.

\section{ACKNOWLEDGMENTS}

We are grateful to Patricia Bustos for DNA sequencing, Paul Gaytan and Eugenio López for the synthesis of the oligonucleotides, Juan Miranda, Brenda Valderrama, and Ernesto Pérez-Rueda for advice and critical comments, Mónica Rosenblueth for cloning the 1.7-kb HindIII fragment into pUC18, Ivonne Toledo for technical assistance, Julio Martínez-Romero for statistical analysis, and Michael Dunn and Les Barran for critically reading the manuscript. R. G. P. was supported by DGAPA fellowship (Facultad de Ciencias, UNAM) and PADEP-UNAM. We also thank O. Lomovskaya for providing pSE380emrAB. Partial financial support was from DGAPA grant IN202097.

\section{LITERATURE CITED}

Altschul, S. F., Gish, W., Miller, W., Myers, E. W., and Lipman, D. J. 1990. Basic local alignment search tool. J. Mol. Biol. 215:403-410.

Baron, C., and Zambryski, P. C. 1995. The plant response in pathogenesis, symbiosis, and wounding: Variations on a common theme? Annu. Rev. Genetics 29:107-129.

Beck, C., Marty, R., Klausli, S., Hennecke, H., and Gottfert, M. 1997. Dissection of the transcription machinery for housekeeping genes of Bradyrhizobium japonicum. J. Bacteriol. 179:364-369.

Brom, S., García de los Santos, A., Stepkowsky, T., Flores, M., Dávila, G., Romero, D., and Palacios, R. 1992. Different plasmids of Rhizobium leguminosarum bv. phaseoli are required for optimal symbiotic performance. J. Bacteriol. 174:5183-5189.

Cava, J. R., Elias, P. M., Turowski, D. A., and Noel, K. D. 1989. Rhizobium leguminosarum CFN42 genetic regions encoding lipopolysaccharide structures essential for complete nodule development on bean plants. J. Bacteriol. 171:8-15.

Colmer, J. A., Fralick, J. A., and Hamood, A. N. 1998. Isolation and characterization of a putative multidrug resistance pump from Vibrio cholerae. Mol. Microbiol. 27:63-72.

Dakora, F. D., Joseph, C. M., and Phillips, D. A. 1993. Common bean root exudates contain elevated levels of daidzein and coumestrol in response to Rhizobium inoculation. Mol. Plant-Microbe Interact. 6: 665-668.

Dixon, R. A. 1986. The phytoalexin response: Elicitation, signalling and control of host gene expression. Biol. Rev. 61:239-291

Eisenschenk, L., Diebold, R., Perez-Lesher, J., Peterson, A. C., Peters, N. K., and Noel, K. D. 1994. Inhibition of Rhizobium etli polysaccharide mutants by Phaseolus vulgaris root compounds. Appl. Environ. Microbiol. 60:3315-3322.

Fahraeus, G. 1957. The infection of clover root hair by nodule bacteria studied by a single glass slide technique. J. Gen. Microbiol. 16:374381.

Friedman, A. M., Long, S. R., Brown, S. E., Buikema, W. J., and Ausubel, F. M. 1982. Construction of a broad host range cosmid cloning vector and its use in the genetic analysis of Rhizobium mutants. Gene 18:289-296.

Griffith, J. K., Baker, M. E., Rouch, D. A., Page, M. G., Skurray, R. A., Paulsen, I. T., Chater, K. F., Baldwin, S. A., and Henderson, P. J. 1992. Membrane transport proteins: Implications of sequence comparisons. Curr. Opin. Cell Biol. 4:684-695.

Hanin, M., Jabbouri, S., Broughton, W. J., Fellay, R., and QuesadaVincens, D. 1999. Molecular aspects of host-specific nodulation. Pages 1-37 in: Plant-Microbe Interactions. Vol. 4. G. Stacey and N. T. Keen, eds. American Phytopathological Society, St. Paul, MN.

Henikoff, S., and Henikoff, J. G. 1992. Amino acid substitution matrices from protein blocks. Proc. Natl. Acad. Sci. USA 89:10915-10919.

Hinrichs, W., Kisker, C., Duvel, M., Muller, A., Tovar, K., Hillen, W., and Saenger, W. 1994. Structure of the Tet repressor-tetracycline complex and regulation of antibiotic resistance. Science 264:418-420.

Hirsch, A. M., and Kapulnik, Y. 1998. Signal transduction pathways in mycorrhizal associations: Comparisons with the Rhizobium-legume symbiosis. Fungal Genet. Biol. 23:205-212.

Hungria, M., Joseph, C. M., and Phillips, D. A. 1991. Rhizobium nod gene inducers exuded naturally from roots of common bean (Phaseolus vulgaris L.). Plant Physiol. 97:759-764.

Jones, J. D., and Gutterson, N. 1987. An efficient mobilizable cosmid vector, pRK7813, and its use in a rapid method for marker exchange in Pseudomonas fluorescens strain HV37a. Gene 61:299-306. 
Klessig, D. F., and Malamy, J. 1994. The salicylic acid signal in plants. Plant Mol. Biol. 26:1439-1458.

Kuc, J. 1995. Phytoalexins, stress metabolism, and disease resistance in plants. Annu. Rev. Phytopathol. 33:275-297.

Kyte, J., and Doolittle, R. F. 1982. A simple method for displaying the hydropathic character of a protein. J. Mol. Biol. 157:105-132.

Lewis, K. 1994. Multidrug resistance pumps in bacteria: Variations on a theme. Trends Biochem. Sci. 19:119-123.

Lisser, S., and Margalit, H. 1993. Compilation of E. coli mRNA promoter sequences. Nucleic Acids Res. 21:1507-1516.

Lomovskaya, O., and Lewis, K. 1992. emr, an Escherichia coli locus for multidrug resistance. Proc. Natl. Acad. Sci. USA 89:8938-8942.

Mao, C., Downie, J. A., and Hong, G. 1994. Two inverted repeats in the nodD promoter region are involved in nodD regulation in Rhizobium leguminosarum. Gene 145:87-90.

Marger, M. D., and Saier, M. H., Jr. 1993. A major superfamily of transmembrane facilitators that catalyse uniport, symport and antiport. Trends Biochem. Sci. 18:13-20.

Martínez-Abarca, F., Herrera-Cervera, J. A., Bueno, P., Sanjuan, J., Bisseling, T., and Olivares, J. 1998. Involvement of salicylic acid in the establishment of the Rhizobium meliloti-alfalfa symbiosis. Mol. PlantMicrobe Interact. 11:153-155.

Messing, J. 1983. New M13 vectors for cloning. Methods Enzymol. 101:20-78

Nakai, K., and Kanehisa, M. 1991. Expert system for predicting protein localization sites in Gram-negative bacteria. Proteins 11:95-110.

Niehaus, K., Kapp, D., and Pühler, A. 1993. Plant defence and delayed infection of alfalfa pseudonodules induced by an exopolysaccharide (EPS I)-deficient Rhizobium meliloti mutant. Planta 190:415-425.

Palumbo, J. D., Kado, C. I., and Phillips, D. A. 1998. An isoflavonoidinducible efflux pump in Agrobacterium tumefaciens is involved in competitive colonization of roots. J. Bacteriol. 180:3107-3113.

Pao, S. S., Paulsen, I. T., and Saier, M. H., Jr. 1998. Major facilitator superfamily. Microbiol. Mol. Biol. Rev. 62:1-34.

Parniske, M., Ahlborn, B., and Werner, D. 1991. Isoflavonoid-inducible resistance to the phytoalexin glyceollin in soybean rhizobia. J. Bacteriol. 173:3432-3439.

Paulsen, I. T., and Skurray, R. A. 1993. Topology, structure and evolution of two families of proteins involved in antibiotic and antiseptic resistance in eukaryotes and prokaryotes - an analysis. Gene 124:1-11.

Perret, X., Freiberg, C., Rosenthal, A., Broughton, W. J., and Rémy, F 1999. High-resolution transcriptional analysis of the symbiotic plasmid of Rhizobium sp. NGR234. Mol. Microbiol. 32:415-425.

Rao, J. R., and Cooper, J. E. 1994. Rhizobia catabolize nod gene-inducing flavonoids via C-ring fission mechanisms. J. Bacteriol. 176: 5409-5413.

Rosenblueth, M., Hynes, M. F., and Martínez-Romero, E. 1998. Rhizobium tropici teu genes involved in specific uptake of Phaseolus vulgaris bean-exudate compounds. Mol. Gen. Genet. 258:587-598.

Rostas, K, Kondorosi, E., Horvath, B., Simoncsits, A., and Kondorosi, A. 1986. Conservation of extended promoter regions of nodulation genes in Rhizobium. Proc. Natl. Acad. Sci. USA 83:1757-1761.

Rouch, D. A., Cram, D. S., DiBerardino, D., Littlejohn, T. G., and Skurray, R. A. 1990. Efflux-mediated antiseptic resistance gene qacA from Staphylococcus aureus: Common ancestry with tetracycline-and sugar-transport proteins. Mol. Microbiol. 4:2051-2062.

Saier, M. H., Jr., Paulsen, I. T., Sliwinski, M. K., Pao, S. S., Skurray, R. A., and Nikaido, H. 1998. Evolutionary origins of multidrug and drug-specific efflux pumps in bacteria. FASEB J. 12:265-274.

Saier, M. H., Jr., Tam, R., Reizer, A., and Reizer, J. 1994. Two novel families of bacterial membrane proteins concerned with nodulation, cell division and transport. Mol. Microbiol. 11:841-847.

Sambrook, J., Fritsch, E. F., and Maniatis, T. A. 1989. Molecular Cloning: A Laboratory Manual. 2nd ed. Cold Spring Harbor Laboratory, Cold Spring Harbor, NY.

Schmidt, P. E., Broughton, W. J., and Werner, D. 1994. Nod factors of Bradyrhizobium japonicum and Rhizobium sp. NGR234 induce flavonoid accumulation in soybean root exudate. Mol. Plant-Microbe Interact. 7:384-390.

Segovia, L., Young, J. P. W., and Martínez-Romero, E. 1993. Reclassification of American Rhizobium leguminosarum biovar phaseoli type I strains as Rhizobium etli sp. nov. Int. J. Syst. Bacteriol. 43:374-377.

Selbitschka, W., Niemann, S., and Pühler, A. 1993. Construction of gene replacement vectors for $\mathrm{Gram}^{-}$bacteria using a genetically modified $s a c R B$ gene as a positive selection marker. Appl. Microbiol. Biotechnol. 38:615-618.

Simon, R., Priefer, U., and Pühler, A. 1983. A broad host range mobilization system for in vivo genetic engineering: Transposon mutagenesis in Gram-negative bacteria. Bio/Technology 1:784-791.

Simon, R., Quandt, J., and Klipp, W. 1989. New derivatives of transposon $\mathrm{Tn} 5$ suitable for mobilization of replicons, generation of operon fusions and induction of genes in Gram-negative bacteria. Gene 80: 161-169.

Spaink, H. P. 1995. The molecular basis of infection and nodulation by rhizobia: The ins and outs of sympathogenesis. Annu. Rev. Phytopathol. 33:345-368.

Wolff, A. B. and Werner, D. 1990. Defense reactions in Rhizobiumlegume symbiosis: Phytoalexin concentration in Vicia faba nodules is affected by the host genotype. Z. Naturforsch. C Biosci. 45:958-962.

\section{Erratum, Volume 13 no. 5, 2000}

In the May 2000 issue of Molecular-Plant Microbe Interactions, the paper by Ramón González-Pasayo and Esperanza Martínez-Romero entitled "Multiresistance Genes of Rhizobium etli CFN42" contained an incorrect E-mail address for the corresponding author. The correct E-mail address is <emartine@ cifn.unam.mx>. In addition, an error occurred in line 10 of the second paragraph. The corrected paragraph reads as follows:

In Phaseolus vulgaris (bean), flavonoid phytoalexins such as phaseollin, phaseollinisoflavan, phaseollidin, kievitone, and coumestrol increase upon wounding, by abiotic stresses, and also in response to viruses or pathogenic rhizobacteria (Dixon 1986). R. etli exopolysaccharide (EPS-) or lipopolysaccharide $\left(\right.$ LPS $\left.^{-}\right)$mutants display enhanced sensitivity to coumestrol and other coumestans from bean roots, indicating that EPS and LPS may act as barriers to restrain the entry of root inhibitory compounds into Rhizobium etli cells (Eisenschenk et al. 1994). In addition, $R$. meliloti EPS and LPS have been implicated in actively suppressing the plant defense response (Niehaus et al. 1993). Salicylic acid is another phenolic compound that has been implicated in plant defense against pathogens (Klessig and Malamy 1994). R. meliloti nodulation factors have been reported to inhibit the salicylic acidmediated defense response in alfalfa (Martínez-Abarca et al. 1998). 